\title{
Learning Management Systems and Student Performance
}

\author{
Khawlah Ahmed, Mujo Mesonovich \\ American University of Sharjah
}

\begin{abstract}
In today's technology driven societies, academic institutions, especially at the tertiary level, are incorporating Information and Communication Technologies (ICTS), utilizing learning management systems (LMS) and adopting blended learning approaches to improve student performance and enhance student learning. Currently a good deal of research is conducted to assess the effectiveness of such techniques and technologies on student learning and performance. A great deal of this research deals with LMS's, e-learning platforms, such as Blackboard, but not much is being conducted on LMS's provided by publishing companies, like McGraw Hill Education, whose course management systems are available for a range of courses and being used throughout the world. This paper examines the effectiveness of McGraw Hill Education's Connect on improving student grades in a pre-calculus course at a university in a Gulf Cooperation Council (GCC) country. Using simple and multiple linear regression analysis to investigate whether there was a relationship between the Connect online assignments' grades and the total course grade of students in the course, and two independent sample t-tests to compare the grades between two pre-calculus courses (one taught using the Connect component, and the other taught in the traditional format) results show that using Connect has positive impact on student grades.
\end{abstract}

Keywords: learning management systems, online learning, technology, teaching, McGraw Hill Education Connect, EFL/ESL learners

\section{Introduction}

Improving student performance, enhancing student learning, and getting students to be active in the learning process continue to be leading priorities in education. To help achieve such goals in today's technology driven societies, academic institutions, especially at the tertiary level, are incorporating Information and Communication Technologies (ICTs), and faculty are busy experimenting with such technology to enhance their traditional methods of teaching. Online learning management systems (LMS) have been shown to have the potential to help support such efforts.

ICTs have been changing the organization of information and how that information is being delivered, creating innovative, transformative learning and resourceful classrooms [1] [2]. With diverse e-learning activities and "programs located at different points of the e-learning spectrum ranging from non or trivial online presence to fully online provision", an "abundance of literature on the use, application, and benefits of learning through Information and Communication Technologies (ICT) in almost all stages of education" [62] and a great deal of research is being produced. Courses which have web/internet-based activities are no longer a novelty in higher education [23]. It is predicted that by 2020 higher education will be adopting "teleconferencing and distance learning to leverage expert resources" where "learning activities will move to individualized, just-in-time learning approaches" and where "hybrid" classes will "combine online learning components with lessfrequent on-campus, in-person class meetings" [4].

Dominating the academic scenes in higher education are the online learning management systems (LMS). Currently a good deal of research is being conducted to assess the effectiveness of using LMS's on enhancing student learning and performance. A great deal of this research concentrates on using LMS's such as Blackboard, Desire2Learn, and Moodle. However, publishing companies, such as Pearson and McGraw Hill Education, are also providing online learning/course management systems that are becoming part of the academic scene in higher education. Their various adaptive and course management systems are available for a range of courses and being used in blended learning contexts as complementary or supportive techniques to the conventional in-class, face-to face instruction methods. McGraw Hill Education's leading course management system, Connect, is being used extensively in higher education institutions around the world, including the Gulf Cooperation Council (GCC) countries in the Middle East (such as the institution in which this study is conducted). According to an article published on their website [41], Connect is currently being used by more than 5 million students and professors, with about 680 course titles and over 71 disciplines across the curriculum.

Based on research conducted by various institutions in the US, in collaboration with McGraw Hill Education, they assert that Connect has been shown to have positive impact on all aspects of the 
teaching and learning process, of importance here are student performance, pass rates, average exam scores, final course grades [58][22]. However, besides these studies conducted in collaboration with McGraw Hill Education, not much research has been conducted on the use of this learning management system. This study examines the effectiveness of this web based tool on course grades in an undergraduate pre-calculus course at a university in one of the GCC countries.

\section{Background Information}

LMS's have been referred to as "learning platforms", “distributed learning systems", " course management systems", "content management systems", “portals", and 'instructional management systems", and "combine a range of course or subject management and pedagogical tools to provide a means of designing, building and delivering online learning environments" [15]. Also known as virtual learning environments, LMS's incorporate interactive technology in the classroom [29] [17] and offer different levels of interaction and potential to create active learning contexts [62].

According to Vázquez-Cano and García [62] a "full-fledged LMS addresses three major requirements: first, it is a completely realized, networked digital environment that includes interactive interfaces for both teachers and students. Second, a LMS provides the content of the curriculum and assessments for teaching and learning in digital form. Third, a LMS includes special tools for managing classroom activity" ( $p$. 63). They explain that "A robust LMS should be able to... centralize and automate administration, use self-service and self-guided services, assemble and deliver learning content rapidly, consolidate training initiatives on a Web-based platform, support portability and standards, personalize content, and enable knowledge reuse" (p.63).

The use of LMS are currently dominating the academic scene in higher education institutions [14] and blended learning approaches are the platforms where interaction and communication are being facilitated by such technology driven resources. Blended learning, with its different models [28] and domains [13], like 'hybrid' approaches to learning [5] [10], such as 'flipping' or 'wrapping' [12] [26] [37], is fairly new, which may account for why there is little consensus about its definition in higher education [59]. Definitions range from viewing it as an integration of online approaches and technologies with some face-to-face interaction [29], to describing it as being a formal education program where learning is done online with some student control on factors such as time and pace, but students still attend the brick- and-mortar school structure [59]. Whatever the definition, it is seemingly taking the lead with "battles over the efficacy of residential learning versus online learning" disappearing, and there is a "quiet adoption of blended learning," with its "attraction of mixed delivery mechanisms" being implemented, "often without transcripting and virtually without announcement" [2]. As things stand right now, the future of academia will see technology being driven by pedagogy in a comprehensive and sophisticated blended learning environment [23].

\section{Impact on learning outcomes}

The pervasive use of digital technologies and online courses has led researchers to question the impact of on-line learning technology on student's educational engagement and learning outcomes. Research conducted has presented somewhat mixed findings. However, while some research conducted showed no significant difference between online and traditional learning [18] [6] [39], a great deal of studies support the effectiveness of using online learning [43] [44] [47] [63], presenting empirical evidence that shows that there is significant positive impact of online, blended and hybrid courses on learning outcomes.

Such positive impact has been attributed to the fact that they not only accommodate pedagogical requirements, disciplines, and course levels, but also student needs [31]. They have positive effects on student interaction, motivation, skills, performance, and achievement [3] [1] [13]. They have been described as being fair in their assessment practices [21] and reported as aiding in helping students become responsible learners who can utilize the knowledge they gained in a variety of contexts [24] [32]. Positive effects on students' academic outcomes and increased student engagement and ownership of learning have been reported, and teachers have also reported that it enables them to be more effective in being able to meet student needs and make fundamental shifts toward higher-value responsibilities [13]. In sum the studies report that such blended learning contexts increase student motivation, ownership of learning, and improve academic outcomes.

According to the McGraw Hill Education Regional Manager (personal communication), their learning/course management system Connect is currently being used across the Gulf Cooperation Countries (GCC) in many of their higher education institutes, as is the case in the university where this study was conducted. Connect has been incorporated in a number of courses in this university, in the hopes of improving the process of learning and teaching of different subjects. It provides support for courses ranging from the Humanities to the Sciences, from courses such as English to Business, Economics, Engineering, to Mathematics. 


\section{Purpose of the study}

There two main goals of this study are:

1. To investigate whether there was a relationship between the Connect online assignments' (homework and quizzes) grades and the total course grade (the accumulative/overall grade the student receives at the end of the semester) for the precalculus course taught in the Fall semester.

2. To compare the students' total course grades from the Fall semester with those of the Spring precalculus course.

\section{Research Methodology}

The focus of this paper is on the use of Connect in the field of Mathematics and Statistics, to investigate the effectiveness of Connect on student grades. The research setting is a pre-calculus course at a university in a Gulf Cooperation Council (GCC) country. Authors in this paper work in this university and have been using Connect in teaching their courses.

The majority of students in the university, and therefore those taking the pre-calculus course, could be characterized as English as a Foreign Language (EFL) or English as a Second Language (ESL) learners. Students who enroll in this course are freshman level students who have not been able to satisfy the Mathematics placement test required by the university and are therefore obliged to register for the pre-calculus course in order to reach competence in basic Mathematics. Once they successfully complete the pre-calculus course, they can then take credit-bearing university mathematics courses. These students have no experience using learning management systems before taking this course.

For this study two pre-calculus courses were examined, one conducted in the Spring semester of 2012, the other offered in the Fall semester of 2012. The pre-calculus course offered in the Spring was taught in the traditional format, with no on-line component. The pre-calculus course offered in the Fall semester of 2012 was conducted in a blended context in which Connect was used for the online assignments (homework and quizzes) which were allotted $10 \%$ of the overall grade of the course (see further details below). These two courses/and or semesters will be referred to as 'Fall' and 'Spring' course/semester, and the Connect online assignments will be referred to as 'homework' and 'quizzes' from here on end. The pre-calculus course in both semesters was taught by the same instructor who is one of the authors in this study. The number of students enrolled in both Spring and the Fall precalculus courses were the same with difference in the ratio of males to females. 30 students (11 males and 19 females) were enrolled in the Spring pre-calculus course, and 30 students (6 males and 24 females) were enrolled in the Fall pre-calculus course.

\subsection{Instruments}

In order to use Connect, the university contacted the McGraw-Hill Education regional representative and set up accounts for its instructors. The instructors and students are provided with the necessary instructions and training that involve creating the course, activating accounts, and navigating through the website. Upon completing registration they are provided with user names and passwords which enable a secure login. They can access Connect via computers or any other portable devices, such as tablets or smartphones. Students can also access various educational resources made available by the instructor, including eBooks, PowerPoint presentations, prerecorded instructor lectures, and additional resources. The process is relatively simple. One of the drawbacks encountered when using Connect is that it is only compatible with specific books, those provided by McGraw Hill Education, and instructors are not able to use books of their choice. So in order to use the books available by the publishing company, instructors need to make sure that the books available on Connect satisfy the learning objectives and outcomes of the course they are teaching.

LMS's offer tools that are quite productive in learning, like file sharing, discussion forums, lesson plans, syllabus, chat, and management of assignments, among others. Connect, as a web-based study program, includes an eBook with quizzes and practice problems on every chapter, and interactive learning tools like audios and videos. Using Connect, instructors are able to create various assignments and projects and follow the students' progress through each assignment, and in the overall course. They have full control on things such as assignment material, including the content, topics, particular problems, number of maximum attempts to complete an assignment and their due dates. The assignments could be selected from chapter templates or by selecting specific questions from the question bank. If the whole chapter template is selected, then all the material in the book needs to be covered, without skipping any topics, or students may not be able to answer the questions that were not covered. All the questions need to be reviewed in an assignment to ensure that the chapter questions are appropriate and aligned with the material covered.

Other options are afforded such as creating one's own questions (but that of course is time consuming), and being able to utilize and modify the same assignments every semester, allowing instructors to save the time and effort of having to continually create new assignments. Another benefit provided by Connect is the grading system. Connect grades the assignment, with the instructor having the 
discretion to define the number of points per question. Depending on the structure of the question, partial credit can be granted for the correct sections of each answer. The grades can also be exported to Microsoft Excel.

As explained above, the study used the learning and assessment tool Connect for the online assignments (comprised of homework assignments and quizzes), which were allotted $10 \%$ (5\% for homework assignments and 5\% for quizzes) of the total/overall course grade, as seen in Table 1.

Table 1. Grade weights and tentative schedule

\begin{tabular}{|c|c|c|c|}
\hline & $\begin{array}{l}\% \\
\text { Grade }\end{array}$ & Dates and time & Location \\
\hline Homework & $5 \%$ & Every 2 weeks & Online \\
\hline Quizzes & $5 \%$ & TBA week in advance & Online \\
\hline Exam 1 & $20 \%$ & $\begin{array}{c}\text { TBA } 2 \text { weeks in } \\
\text { advance }\end{array}$ & In Class \\
\hline Exam 2 & $20 \%$ & $\begin{array}{c}\text { TBA } 2 \text { weeks in } \\
\text { advance }\end{array}$ & In Class \\
\hline Exam 3 & $20 \%$ & $\begin{array}{l}\text { TBA } 2 \text { weeks in } \\
\text { advance }\end{array}$ & In Class \\
\hline $\begin{array}{l}\text { Final } \\
\text { Exam }\end{array}$ & $30 \%$ & $\begin{array}{l}\text { TBA by } \\
\text { administration }\end{array}$ & In Class \\
\hline
\end{tabular}

Only $10 \%$ of the grade was allocated to the online assignments so there would be minimal effect on students' overall grade. In total, there were 10 homework assignments and 5 quizzes (see samples of the questions for these assignments and quizzes on Appendix 1) that were assigned to students using Connect. Homework assignments were given every 2 weeks, with each assignment due every fortnight (2 weeks). Each homework assignment had a minimum of 50 questions that students were required to answer.

For these online assignments, students received immediate feedback upon answering. If their answer was correct, Connect "locks in" the answer and students move to the next question. If the answer is wrong the students have the option of entering a new answer, the second answer is taken as final. In answering the questions, students are allowed to use all the Connect helping tools, at their disposal. These numerous tools (see Appendix 2) are available to offer students help as they complete their assignments.

For each online quiz students were given a time limit (20 minutes) with a maximum of 5 questions. For these questions, Connect helping tools are disabled, which eliminates the possibility of cheating until the quizzes were submitted. To further reduce the possibility of cheating, each quiz was created using the process of pooling, with random questions assigned to each student.

The course grading scale used is a standard grading scale used in the university, see Table 2.

Table 2. Grading scale

\begin{tabular}{|c|c|c|c|c|c|c|c|c|c|c|}
\hline Percent & $\begin{array}{l}95 \& \\
\text { above }\end{array}$ & $\begin{array}{l}90- \\
94\end{array}$ & $\begin{array}{l}86 \\
- \\
89\end{array}$ & $\begin{array}{l}83 \\
- \\
85\end{array}$ & $\begin{array}{l}80 \\
- \\
82\end{array}$ & $\begin{array}{l}77 \\
- \\
79\end{array}$ & $\begin{array}{l}73 \\
- \\
76\end{array}$ & $\begin{array}{l}69 \\
- \\
72\end{array}$ & $\begin{array}{l}63 \\
- \\
68\end{array}$ & $\begin{array}{l}62 \& \\
\text { below }\end{array}$ \\
\hline $\begin{array}{l}\text { Letter } \\
\text { Grade }\end{array}$ & $\mathbf{A}$ & A- & B+ & B & B- & $\mathrm{C}+$ & C & C- & D & F \\
\hline
\end{tabular}

\section{Analysis}

The first goal of the data analysis of this study investigated whether there was a relationship between the Connect online assignments grades and the total course grade for the pre-calculus course taught in the Fall semester. To test if such a relationship existed a scatter plot of the grades was created and linear correlation analysis was conducted. We used simple and multiple linear regression analysis to predict the total grade in the course based on the online assignments and the quizzes in two different ways. The first, in the multiple regression, we predicted the total course grade based on 2 individual grades, the homework assignments and the individual grade of quizzes. The second, in the simple linear regression analyses, we predict the total course grade based on the total grade achieved in the homework assignments and the quizzes together.

For the second goal of the analyses, we wanted to see if there was significant difference between the average of total grades in the Fall and the average of total grades in the Spring semester. We used two independent sample t-tests to compare the grades between the two courses taught in the Spring and the Fall.

\section{Results}

For the first goal of the study, the first undertaking was to look for graphical representation of the data to see if there is any familiar pattern that data could form. The scatter plot of online assignment grades and the total course grades for the Fall semester pre-calculus course, as seen in Figure 1 , reveals pattern of positive linear correlation.

Figure 1. Scatter plot of online assignment grades vs. course grades 


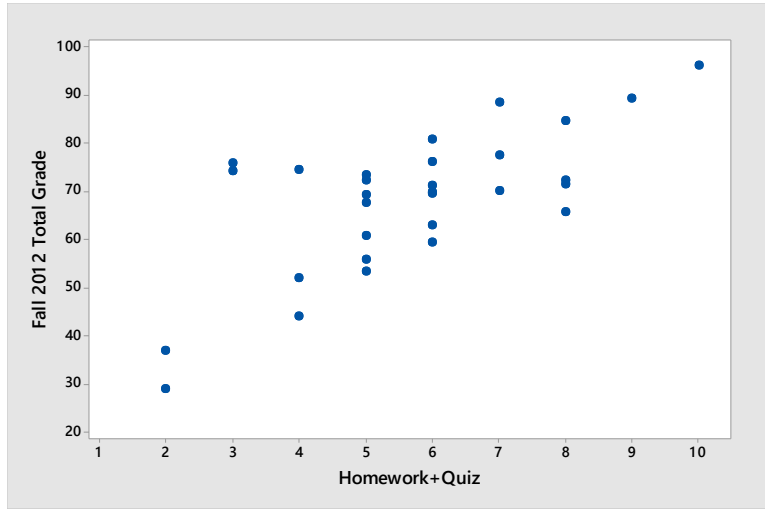

By conducting linear Pearson correlation tests, it was determined that there was significant positive linear correlation between online assignments and course grades, see Table 3.

Table 3.Pearson correlations for online assignments for fall 2012

\begin{tabular}{|l|l|l|}
\hline \multicolumn{3}{|l|}{} \\
\hline Variable & $\begin{array}{l}\text { Pearson } \\
\text { Correlation } \\
\text { Coefficient r }\end{array}$ & P value \\
\hline $\begin{array}{l}\text { Total Grade and } \\
\text { Homework } \\
\text { Assignments }\end{array}$ & 0.539 & $\begin{array}{l}\text { P-value }= \\
0.002\end{array}$ \\
\hline $\begin{array}{l}\text { Total Grade and } \\
\text { quizzes }\end{array}$ & 0.761 & $\begin{array}{l}\text { P-value < } \\
0.001\end{array}$ \\
\hline $\begin{array}{l}\text { Total Grade and } \\
\text { Homework } \\
\text { Assignments } \\
+ \text { Quiz }\end{array}$ & 0.696 & 0.001 \\
\hline
\end{tabular}

The $\mathrm{r}(30)=.539, \mathrm{p}=.002$ indicates strong positive linear correlation between Connect online grades and total course grades (i.e. as the Connect online assignments grade increases, the total course grade will increase). The $\mathrm{r}(30)=.761, \mathrm{p}<0.001$ indicates strong positive linear correlation between Connect assignment quiz grades and total course grades( i.e. as the Connect assignment quiz grade increases the total course grade increases). The $\mathrm{r}(30)=.696, \mathrm{p}<$ 0.001 indicates strong positive linear correlation between Connect homework assignments and the total course grades (i.e. as the homework assignment grades increase the total course grades increase).

Based on the data presented, the authors came up with two models which could be used to predict the total course grade in similar contexts, not included here, but is in the appendix section (see Appendix 3) for those interested in testing these models.

For the second goal of the study, the aim was to compare the students' total course grades from the Fall semester with those of the Spring pre-calculus course. To do this the average of the Fall course grade (68.1) was compared with the class in the Spring which achieved an average of 60.4. An independent two variable T-Test was performed. Students taking the course in the Fall had better grades for the course $(M=68.1, S D=14.8)$ than the students taking the Spring course, $t(55)=1.77$, $\mathrm{p}=.041$. This indicates significant difference between the averages of the two classes at the five percent level of significance. The course taken in the Fall, where the online Connect was used, had a significantly higher average than the course taken in Spring, which was taught in a traditional manner with no online component. This result seems to indicate that the use of the online component, Connect, improved students' total course grades.

\section{Discussion}

The results in this study indicate that the students' grades improved when using Connect, supporting the claims that open learning ecosystems improve students' pass rates, elevate their grades [41] and improve in their learning by outperforming their colleagues studying in traditionally taught courses [11] [57]. However, factors such as availability and easy access to the information at anytime, anywhere may account for this apparent improvement, as has been seen in previous studies [44]. Students in this study had the many Connect help tools provided as they did their homework and quizzes, which the students in the traditional format class did not. These help tools were excellent guides to the information that was needed to understand how to solve the problems and answer the questions they were given and this information was available whenever they needed it. They received immediate feedback, as to whether their answers were correct or not. They were given a range of tools to look at from resource icons that they can just click on and were referred to relevant readings that will help them answer the questions, to unlimited access (of course the instructor can set a limit on the number of times students can check their work and their answers, if they chose to) of hints that provide suggestions, to practice questions to being able to directly send a question to the instructor.

In contrast, students doing the assignments in the traditional class setting, without online support, were disadvantaged in many ways. For one, there was a time lag between submitting an assignment and receiving the graded assignment. During such a waiting period there is always a chance that students lose the immediacy of the assignment and do not learn from the feedback when they eventually receive it. No matter how much faculty want to help their students in a traditional setting, the amount of feedback they can provide and the time they can allocate to each question and or student is also limited. 
Being able to study at their leisure and their own pace meant that learning extended beyond the classroom. . This means more student engagement with the coursework assigned which in turn means students have the time to think and reflect on what has been presented and learned, leading to better understanding [55] deeper approaches to learning [51], and therefore better outcomes [16]. The students who were availed the opportunity to work on Connect also learned many new skills, not only those that dealt with the technology, but with selfregulated learning [50].

Though the results are positive, generalizations cannot be made from the results of this study due to the limited number of students and courses examined. Examining Connect in courses from different disciplines and with larger sample sizes would help to gain a better picture of the effectiveness of Connect. This would also allow for the models developed by the authors to be tested in a variety of contexts. Having the complete course online using Connect, and not just limiting it to the $10 \%$ of homework assignments and quizzes may certainly reflect better results. Other factors that may have impacted students' performance, such as mathematical backgrounds that were not examined. The correlation established between online assessments and the total course grades does not guarantee cause-and-effect relationship between variables [61]. Further research may seek to address factors such as motivation and students' perceptions of online learning for ESL/EFL learners.

\section{Conclusion}

The popularity and effectiveness of on-line learning is anticipated to increase in the future with the adoption of newer technology additions, such as game mechanics, that aim at increasing 'task engagement' and 'decreasing attrition' [20] [34] [35]. Education is being shifted to accommodate for more communication and information access with innovative pedagogies that enable and support the acquisition of knowledge in today's knowledge based societies and lend themselves to developing new skills for lifelong learning motivated by new career paths and working hours [27] [48] [53] [54].

With the demands of today's technology driven academic contexts, teachers need the tools like LMS's that can help them cope, and achieve the goals set for the 21century learning and teaching. They also need the professional development to be able to utilize these course management systems, among the many other tools required by today's technology driven institutions, which requires a great deal of time, effort and trial and error, as was the case with the authors in this study. The end result of the experience, as the authors of this study have found, is that there is no doubt that harnessing technology can enhance learning, whether it is inside or outside of the classroom. The key to enhancing learning tools in the classroom is how effectively they are used [49], and to use them in an effective manner requires a great deal of work, time and patience. As seen, "The effective use of digital resources and provision of opportunities for students to be active participants in building their knowledge and developing their skills is beneficial if the engagement with technology is strongly underpinned by sound educational procedure" [52]. Using technology in class holds the potential to empower not only students but instructors in a variety of ways. It ensures consistency, leaving little, if any, room for human bias and or errors. It also has the potential to deepen the connections between teachers and their students since it allows for more student-instructor face to face interactions.

\section{References}

[1] S. Al-Aonizi, and M. Ally. The use of e-learning in higher education (Dr. Saudsite model). Paper submitted at the Global Forum for Innovation in University Teaching, Imam Muhammad bin Saud Islamic University, Riyadh, Saudi Arabia, 2014.

[2] B. Albrecht. Enriching student experience through blended learning. ECAR Research Bulletin, 2006, 12.

[3] M. Ally. Managing, designing, and implementing "blended learning" for flexible delivery. Workshop handout at the first International Conference in Open Learning, Kuwait., 2013.

[4] J.Q. Anderson, J. L. Boyles, L. Rainie, 2012. [Online] The future impact of the Internet on higher education: Experts expect more-efficient collaborative environments and new grading schemes; they worry about massive online courses, the shift away from oncampus life. Pew Research Center's Internet \& American life Project. Washington, D.C. Available: http://www.pewinternet.org/files/oldmedia/Files/ Reports/2012/PIP_Future of Higher_Ed.pdf, [Acccessed: 14-Apr-2016]

[5] A. Aycock, C. Garnham, \& R. Kaleta, 2002 [Online] Lessons learned from the hybrid course project. Teaching with Technology Today, 8(6). Available: http://www.uwsa.edu/ttt/articles/garnham2.htm. [Accessed 15-May-2015]

[6] R.M. Bernard, E. Borokhovski., R. F. Schmid., R. M. Tamim, \& P.C. Abrami. A meta-analysis of blended learning and technology use in higher education: From the general to the applied. Journal of Computing in Higher Education, vol. 26, no. 1. doi:10.1007/s12528-013-9077-3, 2014, pp. 87-122.

[7] D. Bikowski, \& G. Kessler, Making the most of the discussion boards in the ESL classroom. TESOL Journal, vol. 11, no. 3, 2002, pp. 27-29.

[8] S. Bocconi, P.G. Kampylis, \& Y. Punie. Innovating learning: Key elements for developing creative classrooms in Europe. Spain: European Union, European Commission Joint Research Centre Institute for Prospective Technological Studies, 2012.

[9] S. Bocconi, P.G. Kampylis, \& Y. Punie. Framing ICT-enabled Innovation for Learning:Tthe case of 
one-to-one learning initiatives in Europe, European Journal of Education Volume, vol. 48, no. 1, 2013 , pp. 113-130.

[10] W.G. Bowen, M. M. Chingos, K.A. Lack, \& T.I Nygren, 2012 [Online] Interactive learning online at public universities: Evidence from randomized trials. New York, NY: Ithaka S+R. Available: http://www.sr.ithaka.org/sites /all/modules/contrib/pubdlent/pubdlcnt.php?file=http: //www.sr.ithaka.org/sites/default/files/reports/srithaka-interactive-learning-online-atpublicuniversities.pdf\&nid=464, [Accessed 01-Apr2014]

[11] W.G. Bowen, \& S. lthaka. Interactive learning online at public universities: Evidence from randomized trials. lthaka S+ R, 2012 [Online] Available: http://mitcet.mit.edulwp-contentluploads/2012105/Bo wenReport-2012.pdf, [Accessed 10-Aug-2014]

[12] D.O. Bruff., D.H. Fisher, K.E. McEwen, B.E. Smith Wrapping a MOOC: Student perceptions of an experiment in blended learning, 2013 [Online] MERLOT Journal of Online Learning and Teaching vol.9, no. $2 . \quad$ Available: http://jolt.merlot.org/vol9no2/bruff_0613.htm, [Accessed 02-Nov-2016]

[13] J. Bryson, and A. Jenkins, Understanding and supporting 'blended learning' teaching practices, 2015 [Online] Available: www.edclements.com, [Accessed 02-Nov-2016]

[14] P.S.D Chen, A.D. Lambert, \& K.R. Guidry. Engaging online learners: The impact of Web-based technology on college student engagement. Computers \& Education, vol. 54, no. 4, 2010, pp. 1222-123

[15] H. Coates, R. James, \& G. Baldwin, A critical examination of the effects of learning management systems on university teaching and learning. Tertiary education and management vol. 11, 2005, pp.19-36

[16] K.F. Colvin, J. Champaign, A. Liu, Q. Zhou, C. Fredericks, \& D. E. Pritchard. Learning in an introductory physics MOOC: All cohorts learn equally, including an on-campus class. The international Review of Research on in Open and Distance Learning vol. 15, no.4, 2014, pp. 263-283

[17] P. Daniels, Course Management Systems and Implications for Practice. International Journal of Emerging Technologies \& Society, vol.7, no.2, 2009, pp. 97-108.

[18] C.A. Dell, C. Low, \& J.F. Wilker, Comparing student achievement in online and face-to-face class formats. Journal of Online Learning and Teaching vol. 6, 2010, pp. 30-42.

[19] S. Deterding, D. Dixon, R. Khaled, \& L. Nacke. From game design elements to gamefulness: Defining gamification. In Proceedings of the $15^{\text {th }}$ International Academic Mind Trek Conference: Envisioning Future Media Environments ACM, 2011, pp. 9-15.

[20] J. Dickfos, C. Cameron \& C. Hodgson, "Blended learning: making an impact on assessment and selfreflection in accounting education", Education + Training, vol. 56, no. 2/3, 2014, pp. $190-207$

[21] Discover the impact of Connect on student engagement, grades, and retention rates at 34 universities. [Online] Available: http://www.mheducation.com/highered/ideas/educator /connect-student-discover.html [Accessed 28-Feb2016]
[22] C. Dziuban, \& A.G. Picciano, The evolution continues: Considerations for the future of research in online and blended learning. EDUCAUSE Center for Analysis and Research (ECAR) Bulletin. June 16, 2015

[23] C. Fearon, S. Starr, \& H. McLaughlin. Value of 'blended learning' in university and the workplace: Some experiences of university students. Industrial and Commercial Training, vol. 43, no.7, 2011 [Online]. Available: http://www.emeraldinsight.com/ doijabs/10.1108/00197851111171872 [Accessed 02Nov-2015]

[24] M. Feeley \& J. Parris, An assessment of the PeerWise student-contributed question system's impact on learning outcomes: Evidence from a large enrollment political science course, 2012 [Online] Available: http://ssrn.com/abstract=2144375

[25] G. Fisher. Warming up to MOOC's. The Chronicle of Higher Education Blogs: ProfHacker, November 6, 2012 [Online] Available: http://www.chronicle.com/blogs/profhacker/warmingup-to-moocs/44022 [Accessed 05-March-2015]

[26] G. Fischer \& S. Konomi. Innovative media in support of distributed intelligence and lifelong learning. In Proceedings of the Third IEEE International Workshop on Wireless and Mobile Technologies in Education. Los Alamitos, CA: IEEE Computer Society, 2005, pp. 3-10

[27] J. Fleck, 'Blended learning' and learning communities: Opportunities and challenges. Journal of Management Development vol. 31, no. 4, , pp. 398-411, 2012 [Online] Available: http:/ jdx.doi.org/10.1108/02621711211219059

[28] D. Garrison \& N. Vaughan. Blended learning in higher education: Framework, principles, and guidelines. San Francisco, CA: John Wiley \& Sons, 2008.

[29] H. Genc, Paper and Screen: Reading Strategies Used by Low-Proficient EFL Learners Sino-US English Teaching, vol. 8, no. 10, 2011, pp. 648-658.

[30] J. Gower, 'Blended learning' and online tutoring: A good practice guide, 2006 [Online] Education + Training 48(89). Available: www.emeraldinsight.com/toc/et/48/8\%2F9 [Accessed 05-Oct-2015]

[31] D. Herlo. Benefits of using 'blended learning' in 'performer' education master program. Journal Plus Education vol. 10, no.2, 2014 [Online] Available: http://search.ebscohost.com/login.aspx?dircct=true\&d $\mathrm{b}=$ ehh\&AN=98932949\&site $=$ ehost-live \&scope $=$ site, [Accessed 20-Oct-2016]

[32] P. Hill. Online educational delivery models: A descriptive view. EDUCAUSE Review, vol. 47, no.6 November, 1, 2012, pp. 84-97 [Online] http://www.educause.edu/ero/article/onlineeducational-delivery-modelsdescriptive-view

[33] K. Huotari, \& J. Hamari. Defining gamification: A service marketing perspective. In Proceedings of the $16^{\text {th }}$ International Academic Mind Trek Conference. ACM, 2012, pp. 17-22 [Online] Available: https://www.researchgate.net/publication/259841647_ Defining_Gamification_A_Service_Marketing_Persp ective, [Accessed 04- Feb- 2015] 
[34] K.M. Kapp, The gamification of teaming and instruction: game-based methods and strategies for training and education. US: John Wiley \& Sons, 2012

[35] R. Klamma, M.A. Chatti, E. Duval, H. Hummel, E.H. Hvannberg, M. Kravcik, E. Law, A. Naeve, \& P. Scott. Social software for life-long learning. Journal of Educational Technology and Society, vol. 10, no. 3, 2007, pp. 72-83 [Online]. Available: http://www.ifets.info/joumals/10_3/6.pdf, [Accessed 15-Dec-2013]

[36] D. Koller. How online courses can form a basis for on-campus teaching. Forbes, November 7, 2012 [Online]

Available: http://www.forbes.com/sites/coursera/2012/11/07/ho w-online-courses-can-form-a-basis-for-on-campusteaching/ [Accessed 02-Nov-2015]

[37] K. McCutcheon, M. Lohan, M. Traynor, \& D. Martin. A systematic review evaluating the impact of online or blended learning vs. face-to-face learning of clinical skills in undergraduate nurse education. Journal of Advanced Nursing, vol. 71, no.2, 2015, pp. 255-270.

[38] B.K. McFarlin. Hybrid lecture-online format increases student grades in an undergraduate exercise physiology course at a large urban university. Advances in Physiology Education, vol. 32, no. 1, 2008, pp. 86-91.

[39] McGraw-Hill Education at a Glance, 2016 [Online] Available: https://www.mheducation.com/about.html, [Accessed 24-Feb-2016]

[40] C. McLoughlin, \& M.J.W Lee. The three p's of pedagogy for the networked society: Personalization, participation, and productivity. International Journal of Teaching and Learning in Higher Education, vol. 20, no.1, 2008, pp.10-27 [Online]. Available: http://files.eric.ed.gov/fulltext/EJ895221.pdf [Accessed 16-Feb-2016]

[41] B. Means, Y. Toyama, R. Murphy, M. Bakia, \& K. Jones. Evaluation of evidence-based practices in online learning: A meta-analysis and review of online learning studies. Center for Technology in Learning, U.S. Department of Education, Washington, DC, 2010 [Online] Available: https://www2.ed.gov/rschstat/eval/tech/evidencebased-practices/finalreport.pdf [Accessed 10-Apr2016]

[42] B. Means, Y. Toyama, R. Murphy, \& M. Bakia. The effectiveness of online and blended learning: a metaanalysis of the empirical literature. Teachers College Record, vol. 115, no.3, 2013, pp.1-47 [Online] Available:

http://www.tcrecord.org/library/content.asp?contentid $=16882$ [Accessed 10-May-2015]

[43] J.L. Moore, C. Dickson-Deane, K. Galyen. ELearning, online learning, and distance learning environments: Are they the same? Internet and Higher Education, vol. 14, 2011, pp. 129-135 [Online]. Avaiable: https://scholar.vt.edu/access/ content/group/5deb92b5-10f3-49db-adeb7294847f1ebc/e-Learning\%20Scott\%20Midkiff.pdf [Accessed 23-Aug-2016]

[44] C. Neuhauser Learning style and effectiveness of online and face-to-face instruction. The American Journal of Distance Education, vol. 16, no. 2, 2002 [Online] Available: http://www.rhartshorne.com/fall2012/eme6507-rh/cdisturco/eme6507- eportfolio/documents/neuhauser.pdf [Accessed 12Jan-2014]

[45] T. Nguyen. The effectiveness of online learning: Beyond no significant difference and future horizons. Journal of Online Learning and Teaching, vol. 11, no. 2, 2015, pp. 309-319.

[46] M. Owen, L. Grant, S. Sayers, \& K. Facer. Social software and learning. Bristol, England: Futurelab. 2006 [Online] Available: http://www.futurelab.org.uk/downloadlpdfs/research! opening_educatiou/Social_Software_report.pdf [Accessed 10-March-2014]

[47] R. Owston. The World Wide Web: A technology to enhance teaching and learning? Educational Researcher, vol. 26, no.2, 1997, pp. 27-33.

[48] M. Paechter \& B. Maier, Online or Face-to-Face? Students' Experiences and Preferences in E-Learning. Internet and Higher Education, vol. 13, no.4, 2010, pp. 292-297.

[49] S.Patrick, \& A. Powell. A Summary of research on the effectiveness of K 12online learning, effectiveness of online teaching and learning," iNACOL, 2009 [Online] Available: http://www.inacol.org/research/docs/NACOL_Reseac ]hEffectiveness-Ir.pdf [Accessed 05-April-2014]

[50] D. Prescott. Situated learning, pedagogic models and structured tasks in blended course delivery. In $\mathrm{K}$. Alshahrani \& M. Ally (Eds.), Transforming education in the Gulf region: Emerging learning technologies and innovative pedagogy for the $21^{\text {st }}$ century. New York: Routledge, 2016, pp. 22-35.

[51] Y. Punie. Learning Spaces: an ICT-enabled model of future learning in the Knowledge-based Society. European Journal of Education, vol. 42, no.2, 2007, pp. 185-199.

[52] Y. Punie \& M. Cabrera. The future of ICT and learning in the knowledge society. Luxembourg: European Communities, 2006 [Online] Available: http://ftp.jrc.es/EURdoc/JRC47246.TN.pdf [Accessed 11-April-2015]

[53] S. Riffell, \& D. Sibley. Using web-based instruction to improve large undergraduate biology courses: An evaluation of a hybrid course format. Computers \& Education, vol. 44, no.3, 2005, pp. 217-235.

[54] K.E. Rudestam, \& J. Schoenholtz-Read. The flourishing of adult online education: An overview. In K. E. Rudestam, \& Schoenholtz-Read (Ed.), Harr.d.booh of online learning. Los Angeles, CA: Sage, 2010, pp. 1-18

[55] M. Shachar, \& Y. Neumann. Twenty years of research on the academic performance differences between traditional and distance learning: Summative meta-analysis and trend examination, MERLOT Journal of Online Learning and Teaching, vol. 6, no.2, pp. 318-334, 2010 [Online] Available: http://jolt.merlot.org/vol6no2/shachar_0610.pdf [Accessed 12-June-2014]

[56] The Impact of Connect on Student Success: McGrawHill Connect Effectiveness Study, 2016 [Online] http://ecommerce prod.mheducation.com.s3.amazonaws.com/unitas/hig hered/platforms/connect/ces-2016-impact-of-student [Accessed 11-April-2016]

[57] B. Tolley. Creating successful blended-learning classrooms, 2014 [Online] Available: www.edweek.org/tm/articles/2014/10/08/ctq_tolley_b 
lended_learning.htrnl?qs=bill+tolley [Accessed 11June-2015]

[58] L. Triacca, D. Bolchini, L. Botturi, \& A. Inversini. Mile: Systematic usability evaluation for e-Learning web applications. AACE Journal, vol. 12, no.4, 2004 [Online]

Available: https://doc.rero.ch/record/5377/files/1_Botturi_AACE 2004.pdf [Accessed 01-September-2014]

[59] M.F. Triola. Correlation. Elementary statistics (9th ed.). Boston, USA: Pearson/AddisonWesley, 2005, pp.497-498

[60] E. Vázquez-Cano \& M. García. Analysis of risks in a Learning Management System: A case study in the Spanish National University of Distance Education (UNED). New Approaches in Educational Research, vol.4, no. 1,2015 , pp. 62-68.

[61] D. Xu \& S.S Jaggars. The impact of online learning on students' course outcomes: Evidence from a large community and technical college system. The Economics of Education Review, vol. 37, 2013, pp.4657.

\section{Acknowledgements}

We would like to thank Ms. Madhu Ashok Bathija for the work that she did in this paper.

\section{Appendixes}

\section{Appendix 1}

Sample Questions for Homework and Quizzes

Factor completely:

1. $64 x^{6}-y^{6}$

a) $64(x-y)^{6}$

b) $\left(8 x^{3}-y^{3}\right)\left(8 x^{3}+y^{3}\right)$

c) $64\left(x^{3}-y^{3}\right)\left(x^{3}+y^{3}\right)$

d) $(2 x-y)(2 x+y)\left(4 x^{2}-2 x y+y^{2}\right)\left(4 x^{2}+\right.$ $\left.2 x y+y^{2}\right)$

2. $9 x^{3}-21 x^{2}+18 x$

a) $3 x\left(x^{2}-7 x+6\right)$

b) $3\left(x^{3}-7 x^{2}+6 x\right)$

c) $3 x(x-6)(x-1)$

d) $3 x(x+6)(x+1)$

3. Perform indicated operations and simplify the rational expressions

$\frac{x^{2}-1}{3 x^{2}+6} \cdot \frac{4 x^{3}+8 x}{x^{2}-5 x-6}$

a) $\frac{4 x(x-1)}{3(x-6)}$

$\frac{4 x^{5}+4 x^{3}-8 x}{2 x^{4}-15 x^{3}-18 x^{3}+6 x^{2}-30 x-36}$

$\frac{4 x(x+1)}{3(x-6)} \quad$ d) $\frac{4 x^{5}+4 x^{3}-8 x}{2 x^{4}-33 x^{3}+6 x^{2}-30 x-36}$

\section{Appendix 2}

Connect Tools Available to Help Students as They

Complete Their Assignments

eBook- Students will be able to access their eBook during the assignment by clicking the eBook Links icon that appears with each question. A student who uses this will see relevant readings that may help the student answer that question. This is a good option for practice and homework assignments, or open-book quizzes and tests.

Hint- If a student is unsure of how to go about answering a question, the View Hint link will offer a suggestion.

Allow students to check their work- When a student clicks the "check my work" link after answering a question, a "check" icon will appear if the answer is correct, or an " $\mathrm{x}$ " icon if the answer is incorrect. The actual answer won't be given.

Allow students to ask the instructor-Students can ask their instructors questions about the assignment. They will receive a message in their section homepage with the student's question, and an image of the activity in question, for reference. Instructors can respond directly to that student, or to the entire class if the information is relevant to everyone.

Show special character palette- This is selected if the course is a foreign language, so that students can answer the questions using the appropriate characters.

Show the solutions with the answer- This option appears for certain science, math and engineering questions. On those questions, students will be able to see the solutions. If a question is algorithmic, they can try answering it again with new algorithmic values.

Guide students to the answer- This option appears for certain science, math and engineering questions. On those questions, students can follow step-by-step guides to the solutions and can try answering the questions again with new algorithmic values.

Practice questions- This option is for available for most science, math and engineering algorithmic questions. It allows your students to practice non-scored versions of the assignment questions, with different values. This is best used on assignments intended for increased exposure to, and understanding of, the concepts (rather than assignments meant to assess understanding).

Note: Instructors can apply a percent deduction for using these tools if they chose to)

(Source: The information above was provide by the McGraw Hill Education Representative, Personal Communication)

\author{
Appendix 3 \\ Two Models \\ Model 1: \\ Course Grades $=33.52+0.83 *($ Homework $)+11.48$ \\ *(Quizzes) \\ Model 2:
}

Course Grades $=37.91+5.29 *($ Homework + Quizzes $)$

The following illustrates the use of these two models.

For example, if we have two students who both scored 6 out of possible10 on online homework assignments and quizzes combined: student one had 3 out of 10 for 
homework assignments and 3 out of 10 for quizzes (i.e 6 out of 10), while student two had 4 out of 10 on quizzes and 2 out of 10 for homework (i.e.6 out of 10). In both cases the total quiz and homework assignment is 6 out of 10. For those two examples, Model 2 would predict the same total course grade of 69.65 for both students, while model 1 would predict different grades for the two student: student one's total course grade would be 70.45 and for student two, the total course grade would be 81.1.

In Model 1 (see analysis 1 below) we used the individual scores for online homework and online quizzes. The $\mathrm{p}$ value for the homework variable was 0.002 while the $\mathrm{p}$ value for the quiz variable was close to zero (see Figure 4). Therefore Model 1 is significant at one percent level of significance. In Model 2 (see analysis 2 below) we combined online homework and quiz grades as one variable and the p-value for the new variable was close to zero, therefore Model 2 is significant at one percent level of significance.

Both models could be used for predicting the total course grades for students in similar contexts and or courses that use Connect. The models could predict total course grades in similar classes by obtaining the Connect grade and plugging it into the model equations. For example in Model 2: if a student scored 8 out of the possible 10 on the Connect assignments the grade would be, Total Grade $=37.91+5.29 *(8)=80.23$. Basically knowing only the Connect grade to be 8 (as in this example) we can predict the total course grade to be 80.23. This could be significant for future classes where we can monitor students' progress in Connect and inform students of potential failure/success in the course. The authors realize that the two models could predict totally different grades and it is left to the reader to decide which model to use.

\section{Regression Analysis-Fall 2012 Total Grade versus Homework and Quizzes}

Analysis of Variance

$\begin{array}{lrrrrrr}\text { Source } & \text { DF } & \text { Adj SS } & \text { Adj MS } & \text { F-Value } & \text { P-Value } \\ \text { Regression } & 2 & 3704.94 & 1852.47 & 18.79 & 0.000 \\ \text { homework } & 1 & 16.75 & 16.75 & 0.17 & 0.683 \\ \text { quizzes } & 1 & 1854.19 & 1854.19 & 18.81 & 0.000 \\ \text { Error } & 27 & 2661.79 & 98.58 & & \\ \text { Lack-of-Fit } & 10 & 1653.93 & 165.39 & 2.79 & 0.030 \\ \text { Pure Error } & 17 & 1007.86 & 59.29 & & \\ \text { Total } & 29 & 6366.73 & & & \end{array}$

Model Summary

S R-sq R-sq(adj) R-sq(pred)

$9.9289958 .19 \% \quad 55.10 \% \quad 48.04 \%$

Coefficients

Term Coef SE Coef T-Value P-Value VIF

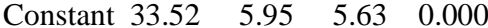

$\begin{array}{llllll}\text { homework } & 0.83 & 2.02 & 0.41 & 0.683 & 1.76\end{array}$

$\begin{array}{llllll}\text { quizzes } & 11.48 & 2.65 & 4.34 & 0.000 & 1.76\end{array}$

Regression Equation

Fall 2012 Total Grade $=33.52+0.83$ homework +11.48 quizzes
2. Regression Analysis-Fall 2012 Total Grade versus Homework + Quiz

Analysis of Variance

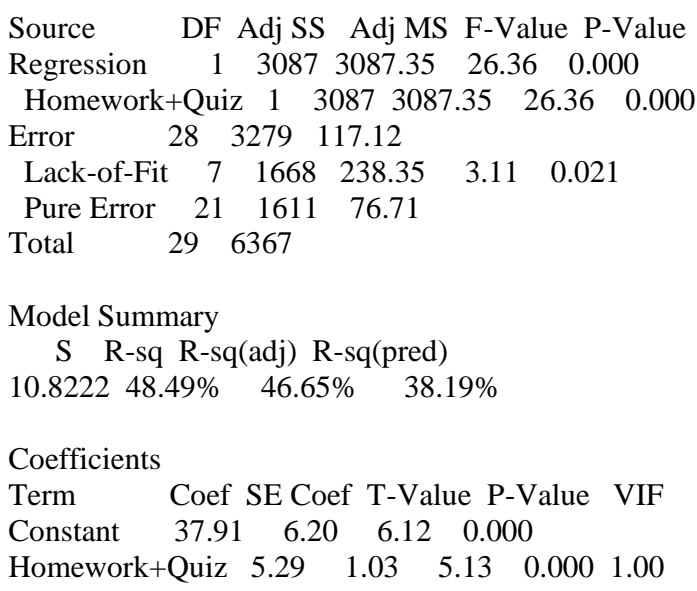

Regression Equation

Fall 2012 Total Grade $=37.91+5.29$ Homework + Quiz Fits and Diagnostics for Unusual Observations

Fall 2012 Std

Obs Total Grade Fit Resid Resid

$\begin{array}{llllll}28 & 75.88 & 53.79 & 22.09 & 2.15 \mathrm{R}\end{array}$

$\begin{array}{llllll}30 & 96.00 & 90.82 & 5.18 & 0.54 & \mathrm{X}\end{array}$

$\mathrm{R}$ Large residual

$\mathrm{X}$ Unusual X

3.Two-Sample T-Test and CI: Spring 2012 Total

Grade, Fall 2012 Total Grade

Two-sample T for Spring 2012 Total Grade vs Fall 2012 Total Grade

N Mean StDev SE Mean

Spring 2012 Total Grade $30 \quad 60.4 \quad 18.7 \quad 3.4$

Fall 2012 Total Grade $30 \quad 68.1 \quad 14.8 \quad 2.7$

Difference $=\mu($ Spring 2012 Total Grade $)-\mu($ Fall 2012

Total Grade)

Estimate for difference: -7.71

95\% upper bound for difference: -0.41

$\mathrm{T}$-Test of difference $=0(\mathrm{vs}<)$ : T-Value $=-1.77 \mathrm{P}$-Value $=0.041 \mathrm{DF}=55$ 